Volume 10 Nomor 22017

\title{
EXPLORING STRATEGIES TO ENHANCE ISLAMIC BANKING'S ROLE TO RAISE CASH WAQF FUNDS
}

\author{
Rizanti Khairunisa \\ Tazkia University College of Islamic Economics \\ rizantikh@gmail.com \\ Nashr Akbar \\ Tazkia University College of Islamic Economics \\ n.akbar@tazkia.ac.id \\ Abrista Devi \\ Ibnu Khaldun University \\ abristasmart@gmail.com
}




\section{Abstract}

Cash Waqf funds has an important role to empower the economy of Ummah. Unfortunately, the collected cash waqf fund is still very small compared to its potential number. Against this background, this research aims to design systems that may enchance the role of Islamic banks in cash waqf fund raising. This paper employed Interpretative Structural Modeling (ISM) by conducting literature studies and In-depth interviews with some regulators, practitioners and academicians. The result shows that experts and practitioners agreed that the strong legal support on cash waqf is necessary to enhance the role of Islamic Banks to raise cash waqf funds. It creates a sense of secure to the stakeholders. Furthermore, it requires a strong coordination between Indonesian Waqf Board (BWI), Ministry of Religious Affairs, Bank Indonesia (BI), Financial Services Authority (OJK), Nazhir and Islamic Financial Institutions that may receive cash waqf (LKS-PWU) in order to boost the role of Islamic Banks. The main obstacle that must be tacled soon is the lack of education about cash waqf.

Keywords: Cash Waqf, Interpretative Structural Modeling, LKS-PWU

\section{Abstrak}

Wakaf uang memiliki peran penting untuk memberdayakan ekonomi umat. Sayangnya, jumlah dana wakaf uang yang berhasil terkumpul masih sangat kecil bila dibandingkan dengan nilai potensinya. Atas dasar ini, penelitian ini bertujuan untuk merancang sistem yang dapat meningkatkan peran bank syariah dalam menghimpun wakaf uang. Penelitian ini menggunakan metode Interpretative Structural Modeling (ISM) dengan melakukan studi literatur dan wawancara yang mendalam kepada para pembuat kebijakan 
(regulator), praktisi dan akademisi. Pendekatan ISM yang digunakan mengacu kepada Saxena, di mana terdapat 9 elemen ISM, diantaranya adalah kebutuhan, masalah, kemungkinan untuk perubahan, tujuan, indicator sukses, kegiatan, pelaku, komunitas yang berpengaruh, dan pengukuran efektifitas. Hasil penelitian menunjukkan bahwa para ahli dan praktisi sepakat akan pentingnya dukungan hukum yang kuat untuk meningkatkan peran bank syariah dalam menghimpun wakaf uang. Hal tersebut dapat memberikan rasa aman bagi para pemangku kepentingan. Lebih lanjut, dibutuhkan koordinasi yang lebih kuat antara BWI, Kementrian Agama, BI, OJK, Nazhir and LKS-PWU guna meningkatkan peran bank syariah. Kendala utama yang mesti juga diselesaikan adalah lemahnya edukasi tentang wakaf uang.

Kata Kunci: Wakaf Uang, Interpretative Structural Modeling, LKS-PWU 


\section{INTRODUCTION}

The understanding of Indonesian people towards waqf is still limited to the object of waqf which is immobile, such as land and building. This may cause lack of people's interest to donate his wealth as waqf. In essense, waqf is not only limited to immobile properties, but also mobile properties, such as cash waqf. Cash waqf is a new innovation in Islamic financial system for voluntary sector. This instrument is able to solve the rigidity of waqf institution in Muslim countries and offer a great opportunity to the development of social economy of ummah in a whole. It also provides opportunity to the whole society to perform waqf in a smaller amount.

In May 11, 2002, Fatwa commision of Indonesian Ulama Council has issued a fatwa on cash waqf. It stated as follows: (1) cash waqf/waqf alNuquud is a waqf performed by an individual, community, instittuition and legal body in the form of cash money, (2) cash includes securities, (3) cash waqf is permissible, (4) Cash waqf should be allocated and used only for anything which complies shariah, (5) principal value of cash waqf should be maintained for its sustainaibility; cannot be sold, given to others and inherited. According to Nasution (2012), the potency of cash waqf in Indonesia is huge. He illustrated that if 20 million of Muslims donate their wealth as waqf for one million per year, then, the potency for collected waqf fund can reach 20 Trilllion. Therefore, it is necessary to have professional waqf institutions thay may manage those funds. The act no. 41 year 2004 about waqf can be used as a basis to develop cash waqf management, where various parties including government, Islam Ummah, Indonesian Waqf Board (BWI) and Islamic financial institutions can work together to develop waqf management in Indonesia.

Based on the act No. 41 year 2004 article 28 to 31, cash waqf funds should be paid through Islamic financial institution approved by minister of religious affair of Indonesia (RI). The ministry has approved 15 Islamic banks to be Cash waqfrecepients as per March 2015, namely Bank Muamalat Indonesia, Bank Syariah Mandiri, Bank BNI Syariah, Bank Syariah Bukopin, Bank Mega Syariah, Bank DKI Syariah, Bank BTN Syariah, BPD Jogya Syariah, BPD Kalbar Syariah, BPD Jateng Syariah, BPD Kepri Riau Syariah, BPD Jatim 
Syariah, BPD Sumut Syariah,

Research conducted by Bank CIMB Niaga Syariah dan Panin Bank Syariah. (Basyuni, 2015)

Unfortonutely, the contribution of cash waqf through Islamic financial Instituion-Recipient of Cash Waqf (LKS-PWU) is not more than Rp 4.115.827.570,(Basyuni, 2015, p.15). This amount is far from its potency. The gap between potency and the realisation indicates that cash waqf in Indonesia has not been managed at optimum yet.

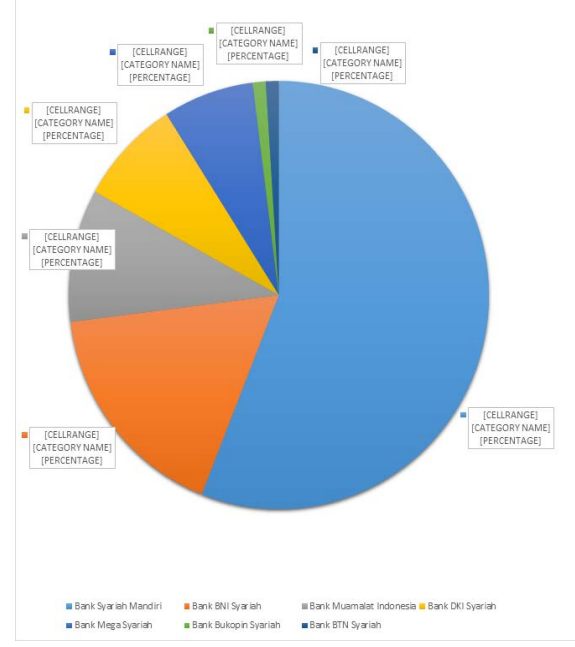

Figure 1: Collected Cash Waqf of BWI Through Islamic Banks Per

31 December 2014

Source:Basyuni (2015, p.16)

IQTISHADIA

Volume 10 Nomer 2017 


\begin{tabular}{|l|l|l|l|}
\hline No & LKS-PWU & $\%$ & Kontribusi Wakaf Uang \\
\hline 1 & Bank Syariah Mandiri & $56 \%$ & Rp. $2,305,406,855$ \\
\hline 2 & Bank BNI Syariah & $17 \%$ & Rp. $719,243,708$ \\
\hline 3 & Bank Muamalat Indonesia & $10 \%$ & Rp. $397,874,114$ \\
\hline 4 & Bank DKI Syariah & $8 \%$ & Rp. $341,116,281$ \\
\hline 5 & Bank Mega Syariah & $7 \%$ & Rp. $276,571,363$ \\
\hline & Bank Bukopin Syariah & $1 \%$ & Rp. $47,658,259$ \\
\hline & Bank BTN Syariah & $1 \%$ & Rp. $27,956,990$ \\
\hline
\end{tabular}

ummah (society). Haron, et al (2016) investigated the potential factors to influence cash waqf collection. The main factors to influence waqf collection are promotion, staffs, method, place of collection and authority. Rusdiyana and Devi (2014) proposed some strategies after identifying cash waqf problems: 1) more computer-based management, 2) developing waqf education institutions, 3) improving the quality of fund managers, and 4) transparency and accountability in every stage of waqf management.

However, those afformentioned studies have not identified the main basic elements to enhance the role of Islamic banks in order to collect cash waqf. Therefore, this research aims to identify key elements and then construct some strategies that may help Islamic banks to raise more cash waqf funds.
2.

\section{I T E R A T U R E REVIEW}

Cizakca (1998) stated that cash waqf has a great potency. Moreover, he proposed the integration of cash waqf and mudharabah in the banking portfolios. Cash waqf which is perpetual in nature is expected to solve the missmatch liquidity of Islamic banks in long-term. Takaful is necessary to maintain the value of cash waqf. Furthermore, Sabit (2011) argued the permissibilty of establishing a bank on the basis of waqf, where waqf funds can be used as capital similar to the common banks.

Nafis (2011) studied the implementation of cash waqf in Indonesia. He found that the collected waqf funds should be allocated by nazhir into various business sectors which comply shariah (halal) and productive. The funds can be invested in the products of Islamic financial 
institutions. The investment will be protected by Islamic insurance.

In relation to Islamic Financial institution, Zamhari (2011) did a research on the implementation of Islamic Financial Intsitutions in developing cash waqf in Indonesia. The result shows that the role of Islamic financial institution (LKS) in developing cash waqf has a strong legal basis as stipulated in the act No. 41 year 2004. Besides, LKS has a wide network, compatible human resources, and Deposit Insurance Corporation that guarantee the safety of waqf funds. However, there are some challenges: lack of nazhir, the difficulty of LKSPWU to the explain to the prospective waqif about the real project, different understanding among LKSPWU, BWI and Kemenag about some points in the codes of conduct. In relation to those challeges, BWI and LKS-PWU need to synergize in the waqf socialization to the whole society.

\section{Furqon} analyzed the practice of cash waqf in Islamic financial institutions, especially in Bank SyariahMandiri. $\mathrm{He}$ made some conclusion from his study; 1) the dissemeniation of cash waqf is relatively limited, 2) BSM has no a specific counter that may serve customers who is willing to register/donate cash waqf, 3) there are two investment models for cash waqf in the bank: investment in real sectors such as buildng a maternity hospital, and in financial sectors, where the funds are depositied in the term deposits of bank syariahmandiri.

In relation to the small number of waqf collection, Mikail (2013) argued that it is due to lack of support and participation of government. Siswantoro and Dewi (2011) argued that ineffectiveness of cash waqf institutions is caused by, 1) lack of government support, 2) the understanding of people about waqf is still limited to physical asset.

Rusdiyana and Devi (2014) studied the problems of cash waqfmanagement in Indonesia. They found four basic problems: 1) Human aspect, 2) Trust aspect, 3) System aspect and 4) Shariah aspect. Using ANP method, the result shows that the main problem is trust (most priority), then shariah, human resource and last is system. Therefore, they proposed some strategies as follwos: 1) management with computer basis, 2) developing waqf 
education institutions,

3) increasing the ability of nazhir, 4) transparancy and accountability in every stage of wqaf management.

Ubaid (2014) analyzed the result and method of fundraising cash waqf of BWI. He found that the performance of BWI in collecting funds is instable (up and down). This is due to working rhythem of BWI. Compared to other nazhirs, the amount of cash waqf collected by BWI is lower. Therefore, BWI must consider to use other methods to fundraise at maximum. Of the methods are collecting funds from membership, offering letter through direct email, employing voluntary labor force, and utilize the funds of the company. Moreover, BWI should create a special division assigned to fundraise cash waqf.

$$
\text { Mu'allim }
$$

Abdurrahman proposed cash waqf as a tool that may increase people's welfare. Cash waqf can be utilized as a new source to activate potential economy emporwment sectors. Even though, there are still many challenges in the implementation, hence, cash waqf should be developed by strengthening the regulation, institutions, and cooperation with other institutions.
Osman et al (2012) studied variables that may influence the willingness of people to make a waqf donation. By doing literature survey, they found six factors at least:1) spiritual satisfaction, 2) understanding about waqf, 3) trust, 4) demography, 5) inefficient management, 6) tax incentives.

$$
\text { Al-Arif }
$$

explored about community empowerment through cash waqf. He argued that cash waqf has a significant role to design community empowerment programs. He emphasized that community empowerment is not a task of government only, but every segment of community must participate in the economic empowerment. The collection and management of cash waqf can be integrated with Islamic financial institutions. Nazhir is assigned to invest those funds in the projects wich comply shariah with one requirement: the nominal value of cash waqf invested should be maintained, not deminishes. The result of investment is allocated for nazhir fee $(10 \%)$ and people's welfare (minimum 90\%). 


\section{METHODS}

Source and Methods of Data Collection

The data used in this research is primary data obtained from interviews with experts and practitioners. Selected respondents are those who are considered to have a good understanding of cash waqf development in Indonesia and those who work for the LKS-PWU and waqf regulators (BWI and the Ministry of Religious Affairs). The'group' of respondents was designed to be unconventional in its defined criteria. The criteria for respondents from the practitioners group are: 1) the respondents have been working for the LKS-PWU and have main job descriptions involving collecting cash waqf; 2) the respondents must also have experience of collecting cash waqf; and 3) the respondents are considered knowledgeable about the role the LKS-PWU plays in collecting cash waqf. The criteria for respondents from the regulator group are: 1) the respondents are involved in cash waqf regulation development; 2 ) the respondents are considered knowledgeable about the role the LKS-PWU plays in collecting cash waqf; and 3 ) the respondents are considered to have written or spoken publicly on at least one theme regarding the role of LKSPWUs in collecting cash waqf. After identifying the criteria of each group respondent, nine respondents are selected. There is no maximum or minimum requirement in choosing a respondent, the mostimportant thing to be considered is that they must have expertise in the discussed topic.

\section{Beside}

interviews, this research also studied literatures dealing with the problems encountered in the implementation cash waqf funding. Some sub-elements of Strategies to strengthen the Role of Islamic Banks in collecting cash waqf are obtained from the literatures and discussion. Those strategies will be expressed in the form of a questionnaire by using the approach of Interpretative Structural Modeling (ISM), referring to Saxena with his nine elements, namely needs, constraints or problems, possible changes, goals, benchmarks of success, activities, actors (stakeholders), affected communities, and measures of effectiveness.

General Description on Interpretative Structural Modelling Method 
Interpretative Structural Modeling (ISM) is a modeling technique developed for planning strategic policies (Marimin: 2004). ISM was first invented by J. Warfield in 1973, where Warfield defines the ISM as computer-assisted learning process that allows individuals or groups to develop a map of the complex relationship between the various elements involved in complex situations.

I $n t$ e r p r e $t$ a $t$ v e Structural Modeling (ISM) as applied by Bhattacharya and Momaya (2009), is an advanced interactive planning methodology that allows a group of people, working as a team, to develop a structure that defines the relationship between the elements in a set. Structures obtained by answering simple questions. Elements that will be structured (such as goals, obstacles, problems, and so on) are specified at the beginning of the ISM planning session. ISM process starts at the modeling system and ends with the validation of the model. Through the ISM techniques, raw models that are not clear is transformed into a visible system model.

\section{RESULT DISCUSSION}

\section{Element of Needs}

Results of the ISM processing on element of needs can be seen below, with details as follows:

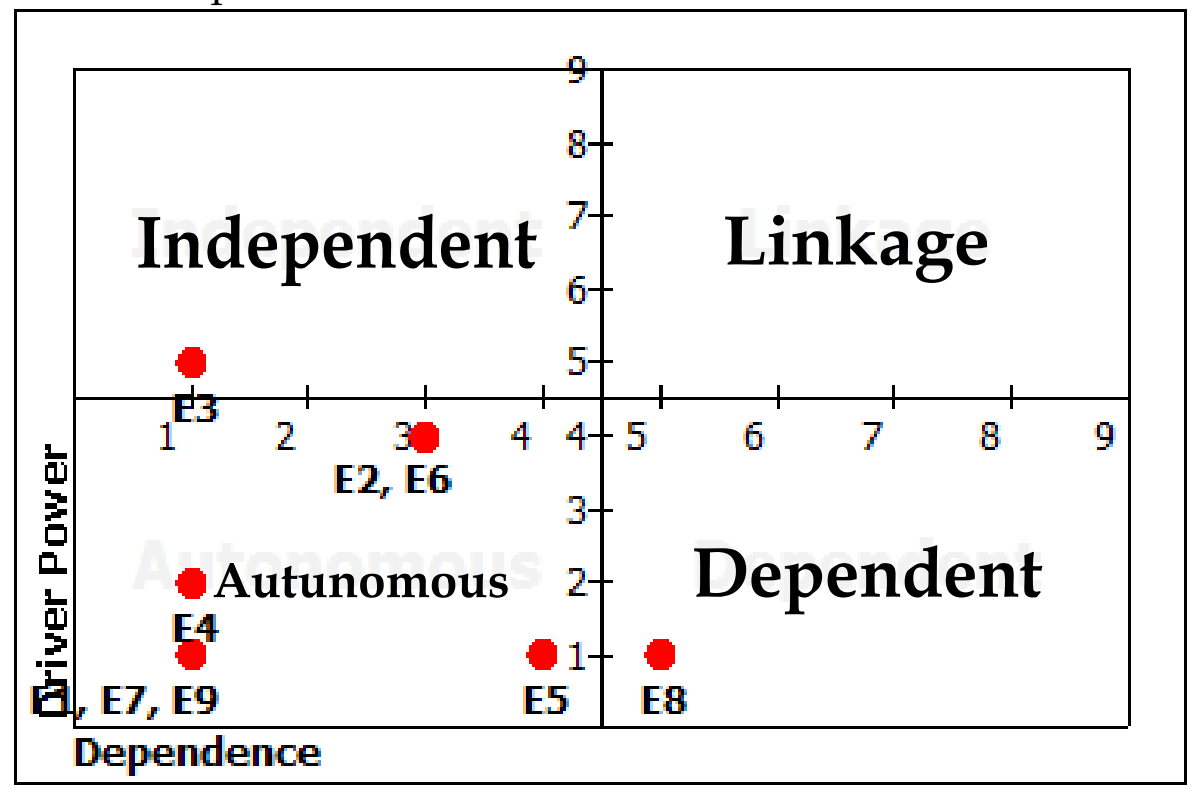

Figure 2: Power-Dependence Driver Matrix for Element of Needs 
Six sub-elements

result of other elements. Subare included in a group of element (E3) legal support for autonomous, namely (E1) cash waqf contained in the optimizing the role of LKS- independent sector, which is PWU,

education/ socialization of cash waqf, variables that affect the other (E9) establishing a special elements if there is a change.

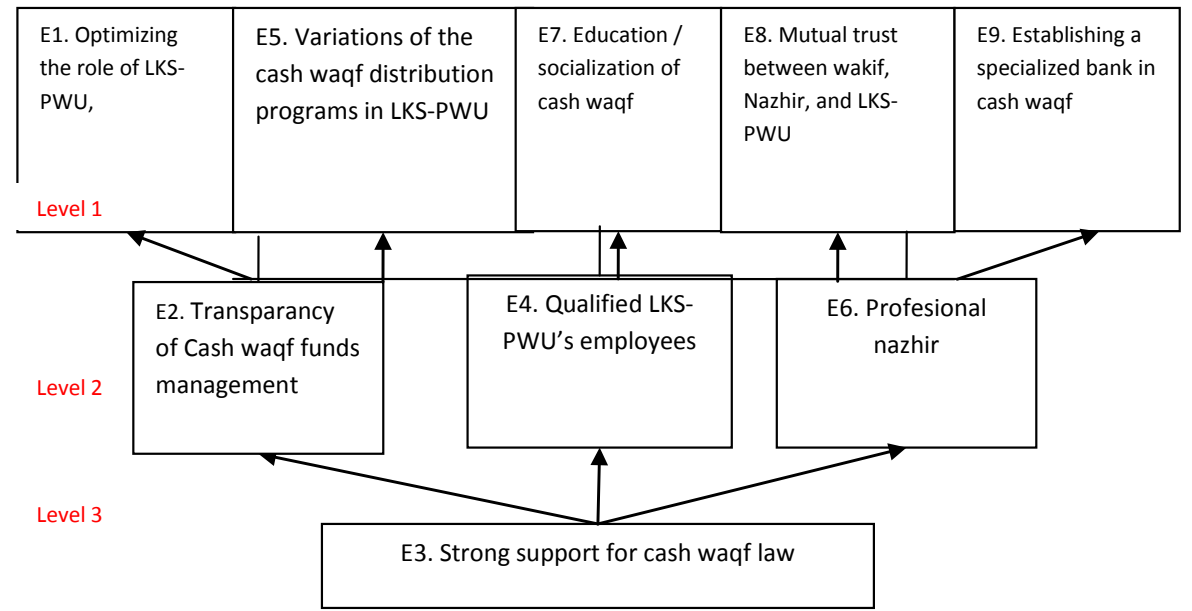

Figure 3: Structural Model for Element of Needs

bank in cash waqf, Variations of the cash waqf distribution programs in LKS-PWU (E4) Qualified LKS-PWU's employees, (E2) transparancy of Cash waqf funds management, while (E6) Professional Nazhir, a sub-element which is connected to the system. Subelement (E8) mutual trust between wakif, Nazhir and LKS-PWU is in the dependent group, which means having a close relationship with other elements, but not the prime mover of the system or it can be interpreted as the
The above figure shows the sequence of stages of needs in the implementation of the strategy to enhance the role of Islamic banks in the collection of cash waqf. The lowest level, level 3, is the key sub-element of the elements of needs, means strong legal support for cash waqf has the most impact. Cash waqf law has been resolved, but there are still a lot of confusion regarding boundaries, systematic cash waqf, sanctions for those who do breach the rules. It requires the firmness on the law in order to create a sense of 
security and discipline in the LKS-PWU is less than optimal, implementation of cash waqf.

(E2) lack of transparency in

Element of Obstacles or Problems

the management of cash waqf, (E4) Lack of qualified LKSPWU's employees and (E8) Lack of trust Among wakif,

The result of ISM Nazhir and LKS-PWU. Sub process for elements of elements that are in the sector constraints or problems can be need to get a more thorough seen in the following points in analysis, since it has a strong details:

driving force and can have an

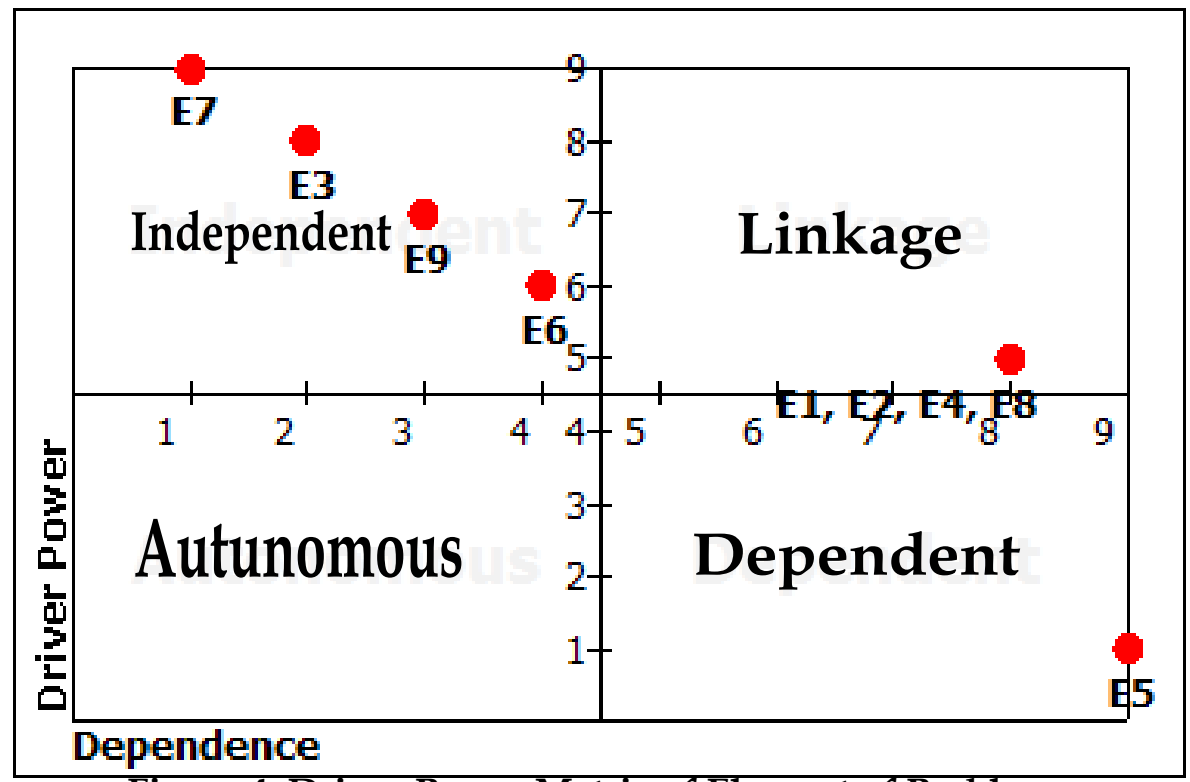

Figure 4: Driver-Power Matrix of Element of Problems

Of the nine subelements, sub-elements(E5) the lack of variety of distribution cash waqf products in LKSPWU is in a dependent group, which means having a close relationship with other elements, but not the prime mover system or it can be interpreted as the result of other elements. Another group is the linkage, there are four subelements namely (E1) role of

impact as well as feedback to the system. The next group is independent elements, independent variables that affect the other elements if there is a change, namely (E7) less education/socialization of cash waqf (E3) Lack of legal support on cash waqf, (E9) the absence of a specialized bank in cash waqf, and (E6) the lack of professionalism of Nazhir. 
-...

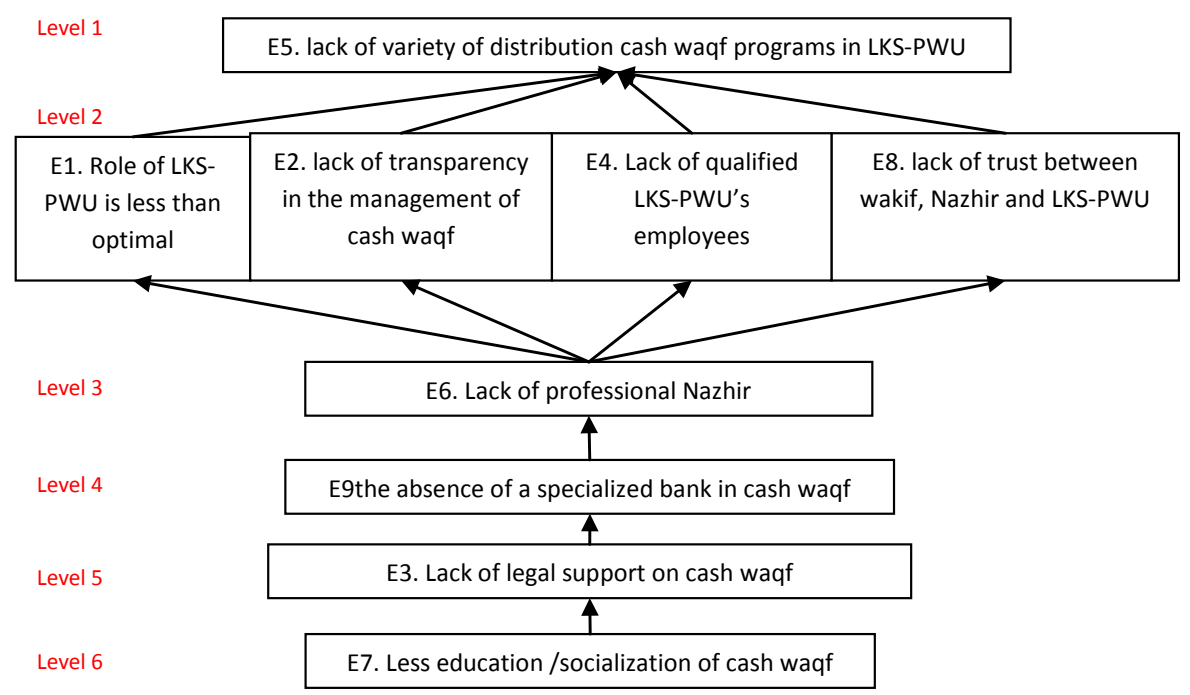

Figure 5: Structural Model for Element of Obstacles or Problems

In the structure of process could be done through element of problems above, it public service, the call of can be seen that Less education important religious leaders, as /socialization of cash waqf well as in teaching in schools. become the key sub-element of element of problems. Element of Possible Changes More intensified education/ socialization of cash waqf Results of ISM proces is required to increase the for element of possible changes public interest to donate waqf. can be seen as follows:

The education/socialization

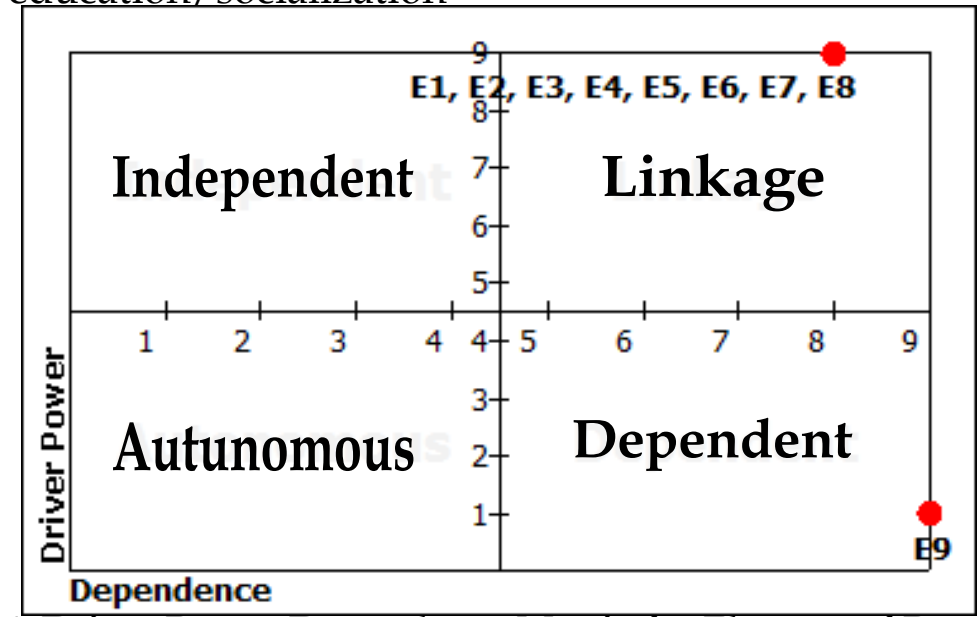

Figure 6: Driver Power-Dependence Matrix for Element of Possible Changes 
Of those nine subelements, sub-element (E9) To establish a specialized bank in cash waqf is in the dependent group, which means has a close relationship with other elements, but not the prime mover of the system or it can be said the result of other elements. The next group is linkage, there are eight sub-elements in this group namely (E1) To standardize the role of LKS-PWU, (E2) Transparency of cash waqf funds management using IT, (E3) Legal Support and strict sanctions for non-compliance, (E4) Knowledge/skills of LKSPWU's employees about cash waqf, (E5) Having Various distribution cash waqf product in LKS-PWU, (E6) To provide certification for professional Nazhir, (E7) Education, socialization and effective communication, (E8) Fostering good relations between wakif, Nazhir, andLKS-PWU.
The above element structure model of possible changes show the need of standardization of the role of LKS-PWU in order to improve the performance of LKS-PWU to fundraise cash waqf to be more efficient. Besides, transparancy in the management of cash waqf can be done by publication in the website, magazines and others. Transparancy may bring a secure feeling and trust toward nazhir for managing cash waqf. The use of IT for transparancy is necessary to provide systemation information to the communities about the management of cash waqf every month. To provide certification for professional nazhir can be considered as an appreciation to the good performance of nazhir. A professional nazhir should be able to educate people about cash waqf, hence, it may increase the public interest to

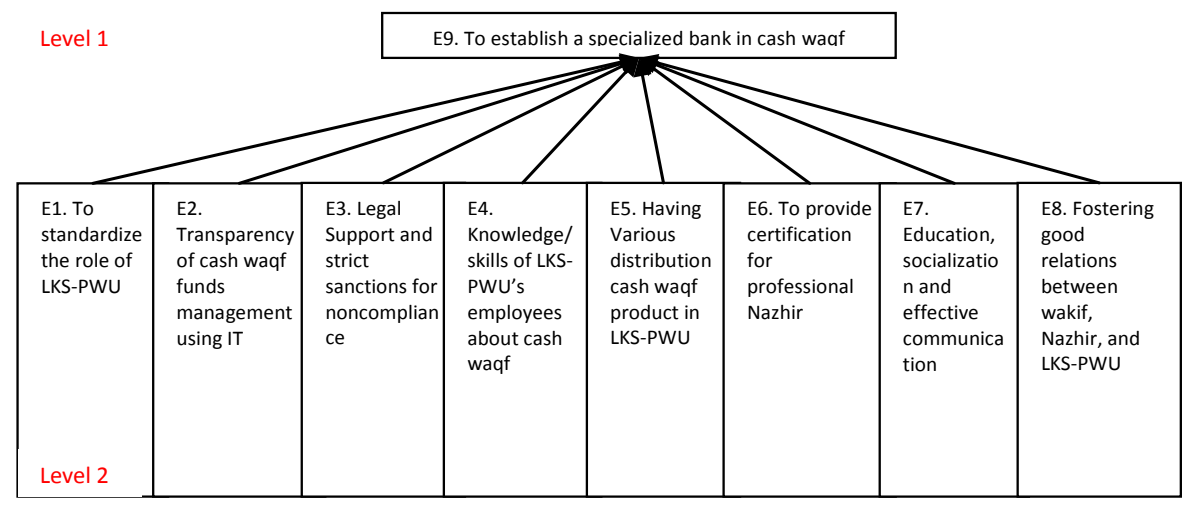

Figure 7: Structural Model for Element of Possible Changes 
donate waqf. In addition, the relationship between nazhir, wakif and LKS-PWU shuld be fostered to sow the trust toward cash waqf management in Indonesia. If every thing runs well, the establishment of specialized bank in cash waqfis possible, and it may assist the management of cash waqf funds to be more productive. The waqf banks should comply with the syariah in the whole transactions.

\section{Element of Purposes}

Results of ISM process for the element of purposes can be seen below, with details as follows:

Sub-element

which means having a close relationship with other subelements, but it is not the prime mover of the system or it can said as results of other sub-elements. The other group is linkage group consisting of seven sub-elements: (E2) Having a transparent cash waqf funds management, (E4) Improving the quality of employees of LKS-PWU, (E5) Availability of various cash waqf distribution products of LKS-PWU, (E6) Availability of Nazhir professional, (E7) Availability of education system, socialization and effective communication, (E8) Increased trust between (E1) wakif, Nazhir and LKS-

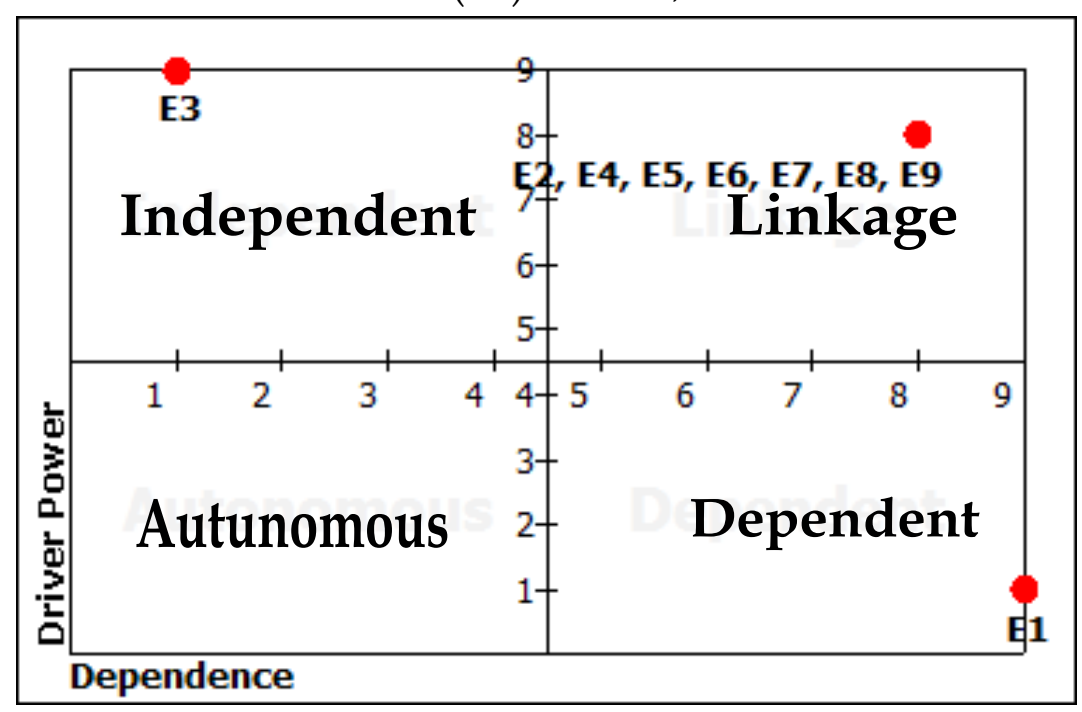

Figure 8: Drive Power-Dependence Matrix of Element of Purposes

Achieving the optimal role PWU, (E9) Availability of of LKS-PWU is classified specialized banks in cash waqf. in the dependent group Meanwhile, sub-element (E3) 
Availibitlity of legal support for cash waqf is categorized in the independent group and it has been decided as key subelements.
To conclude, sub element (E7) the level of public knowledge about cash waqfisin autonomous group, while sub-element

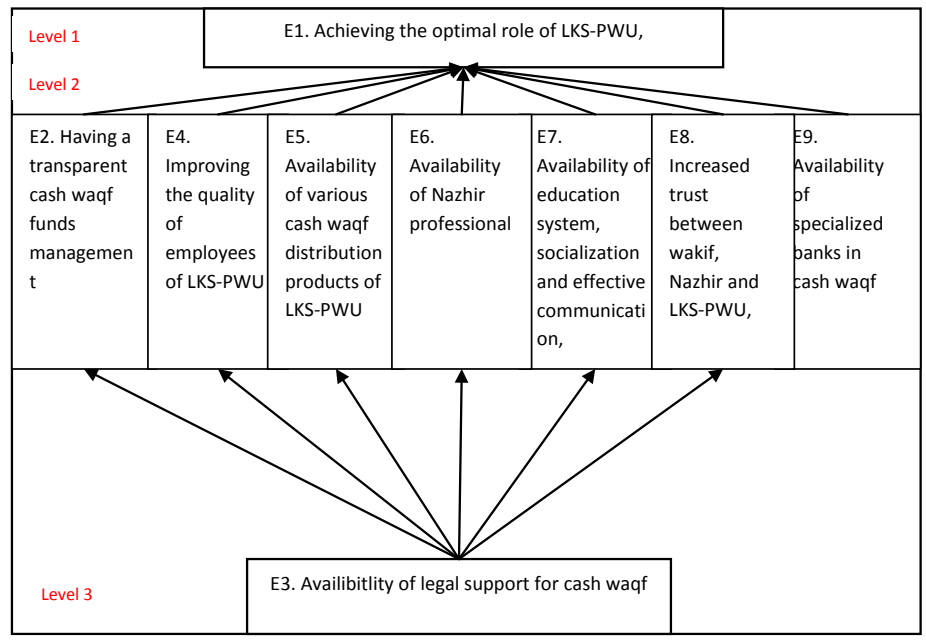

Figure 9: Structural Model for Element of Purposes Element of Success Measurements

Element of Success (E2) Transparency of cash Measurements waqf fund management, (E8) Increased trust among Results of processing wakif, Nazhir and LKSelement success measurements PWU, (E9) the establishment can be seen below: of a specialized bank in cash

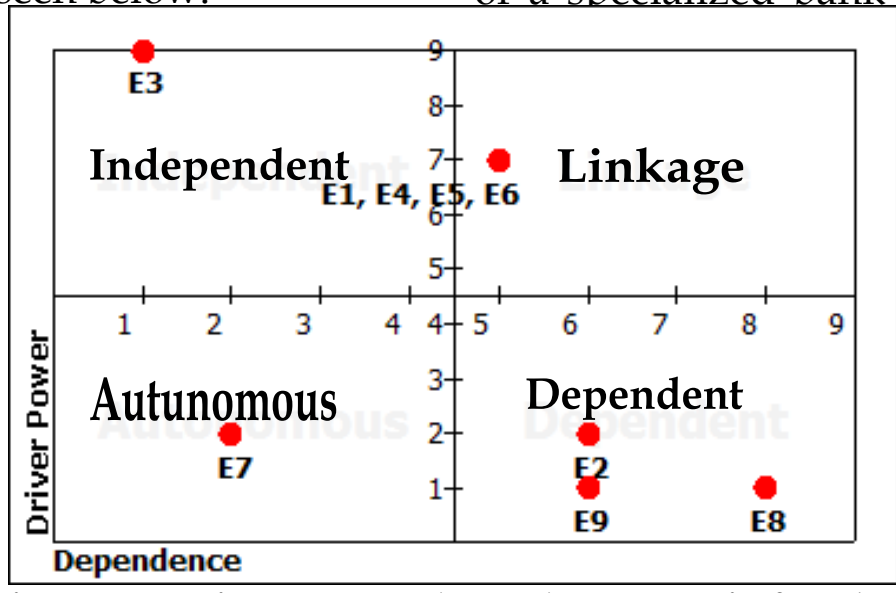

Figure 10: Driver power-dependence Matrix for Element of Success measurements 
waqf are in dependent group, is (E3) legal support for cash which means they have a waqf (key sub-element)

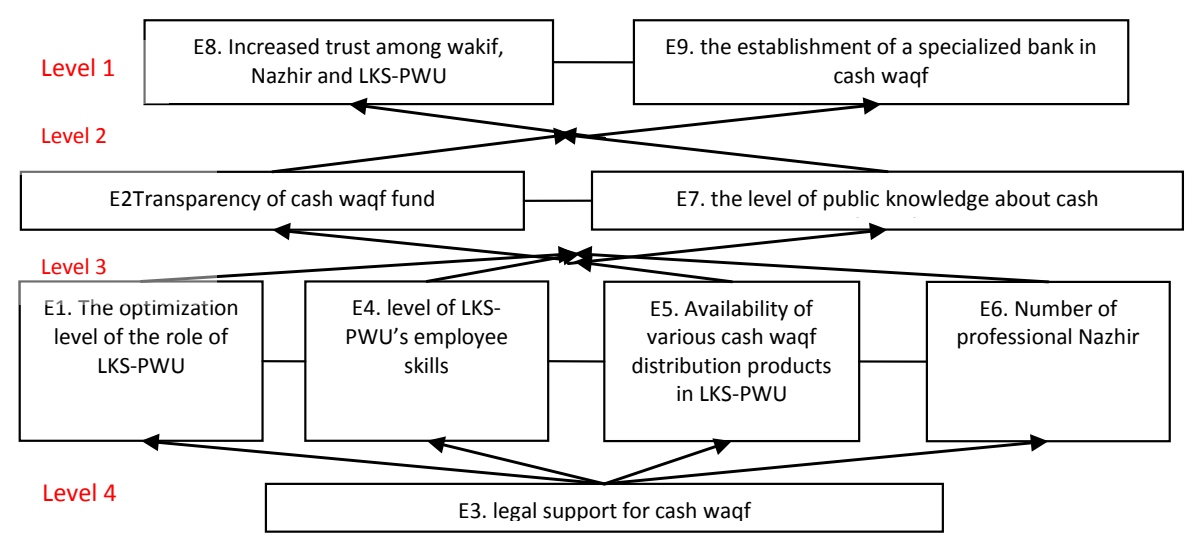

Figure 11: Strucural Model for Element of Success Measurement

close relationship with other elements, but not the prime mover of the system or it can be said as a result of the other elements. Third group is linkage group. There are four sub-elements in the group; (E1) The optimization level of the role of LKS-PWU, (E4) the level of LKS-PWU's employee skills, (E5) Availability of various cash waqf distribution products in LKSPWU, and dan(E6) Number of professional Nazhir. Sub elementsin the group must be analyzed more carefully, because it has a strong driving force and can have impacts as well as feedback to the system. The fourth group is independent elements that may affect the other elements if there is a change. Subelement included in the group
The key sub-element of success measurement is the legal support for cash waqf. The legality of cash waqf has been issued since 2004, but the problem lies in the absence of strict sanction for those who break the law, hence, the legal support must be more strengthened. With strong legal support, the other sub-elements will be achieved easier.

\section{Element of Activities}

Results of processing the elements can be seen below, with details as follow: 


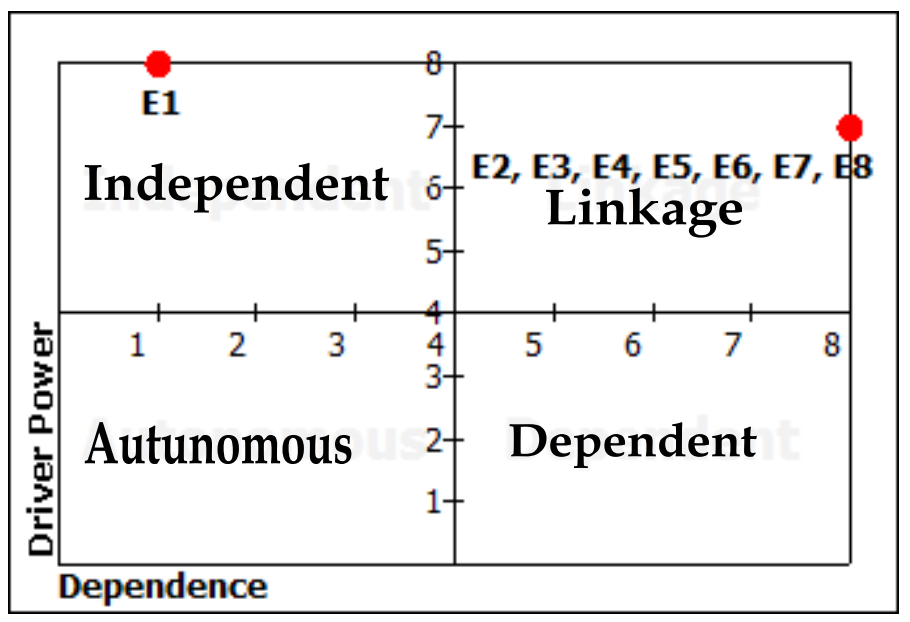

Figure 12: Driver Power-dependence Matrix for Element of

\section{Activities}

Sub-element

(E1) coordination includes the Coordination among BWI, views and understanding Ministry of Religious Affairs, about cash waqf, system, Bank Indonesia, Financial sanctions, and others. Service Authority (OJK), Meanwhile, other elements are Nazhir and LKS-PWU in order in linkage group that must be to boost the role of LKS-PWU analyzed carefully, since they becomes the key sub-element have strong driver power, as it lies in the independent created impact and provide sector that may influence feedback to the system. the other sub-elements. The

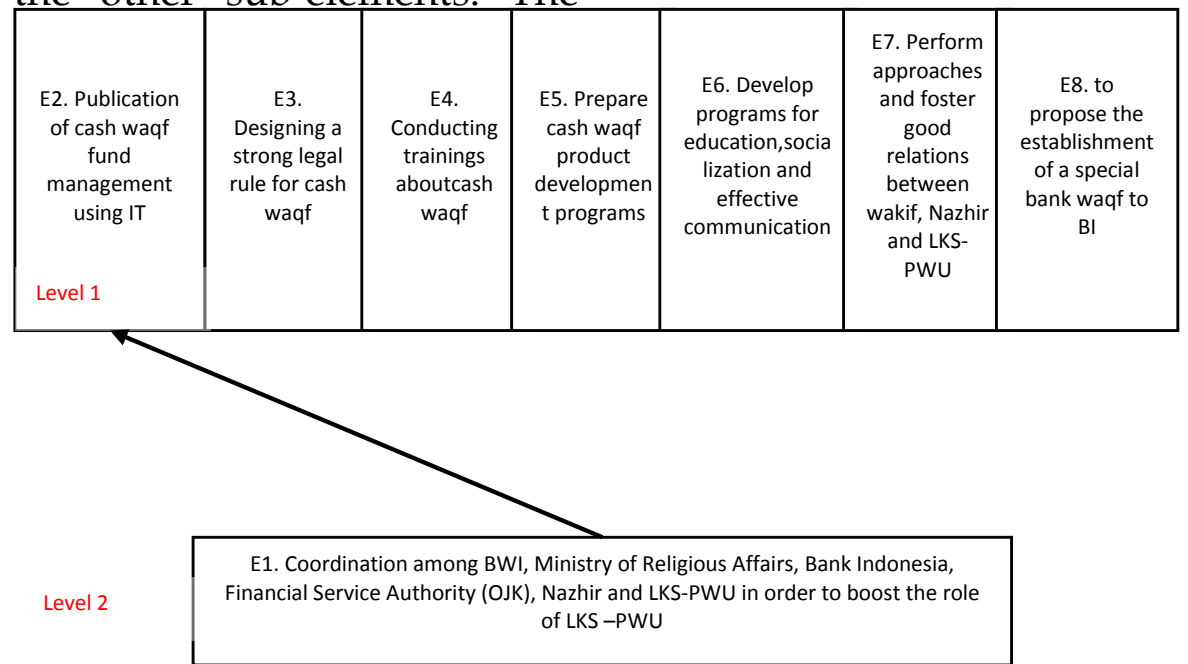

Figure 13: Structural Model for Element of Activities 
Element of Actors or be said as a result of the other Institutions elements. The other group is linkage group consisting of The result of ISM five sub-elements: (E1) the process is as follows: ministry of religious affairs

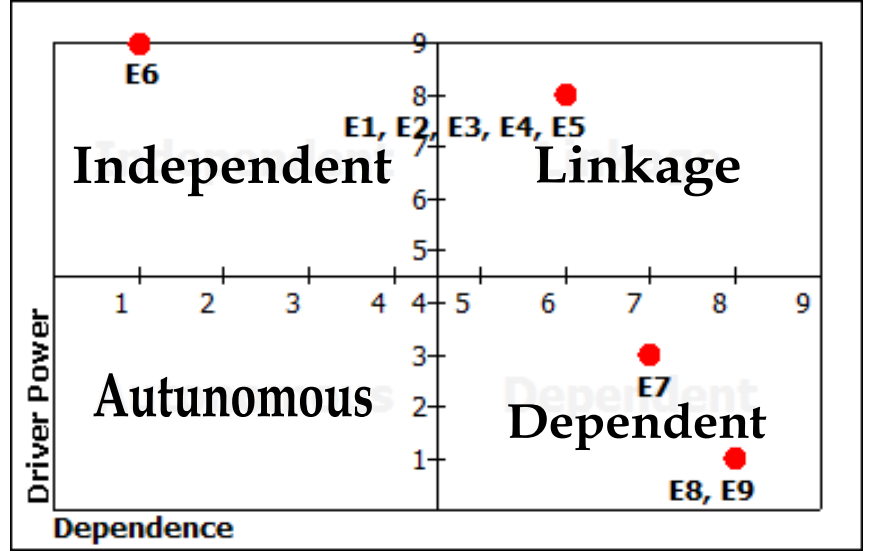

Figure 14: Driver Power-Dependence Matrix for Element of actors

Sub-element nazhir, (E8) wakif,
(E2) Indonesian (E9) Waqf Board (BWI), (E3) LKSsociety is in dependent group PWU, (E4) BI, and (E5) OJK. which means they have a Sub-element included in the close relationship with other group independent is (E6) elements, but not the prime DSN-MUI, this sub-element is mover of the system or it can defined as key sub-element

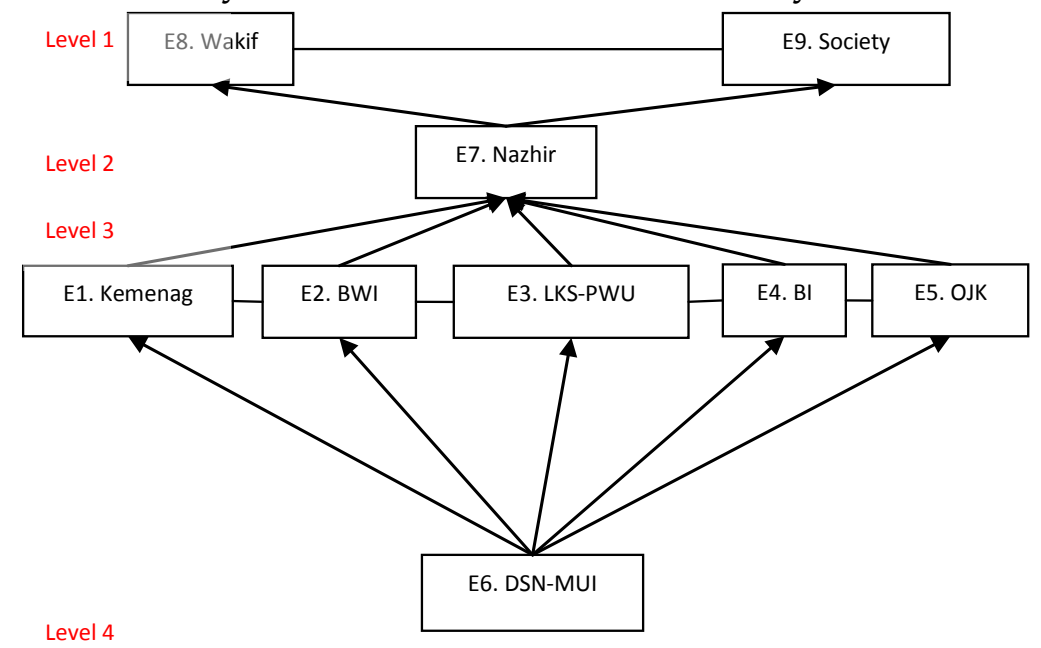

Figure 15: Structural Model for Element of Actors 
Nazhir plays an important role to enhance the collection of cash waqf funds. Nazhir must have high intellectual capability about waqf and have a special ability to manage investments. Nazhir is able to pursue people to donate his waqf funds through registered LKS-PWU by doing intense socialization to the potential waqif. Kemenag, BWI, LKS-PWU, BI, OJK coordinate to supervise the development of cash waqf fundraising. DSN-MUI acts as shariah supervisor and a mediator of misunderstanding between related parties.

Element of Affected People Segment

Results of ISM process can be seen below:

\section{Sub-element}

Islamic Financial InstitutionsCash Waqf Recipients (LKSPWU), (E7) nazhir, (E8) wakif, (E9) society is in dependent group which means they have a close relationship with other elements, but not the prime mover of the system or it can be said as a result of the other elements. The other group is linkage group consisting of four subelements: E1) Ministry of Relegious Affairs (kemenag), (E2) Indonesia Waqf Board (BWI), (E4) Bank Indonesia (BI), dan (E5) Financial Service Authority (OJK). Subelement of independent group is (E6) DSN-MUI, defined as key sub-element.

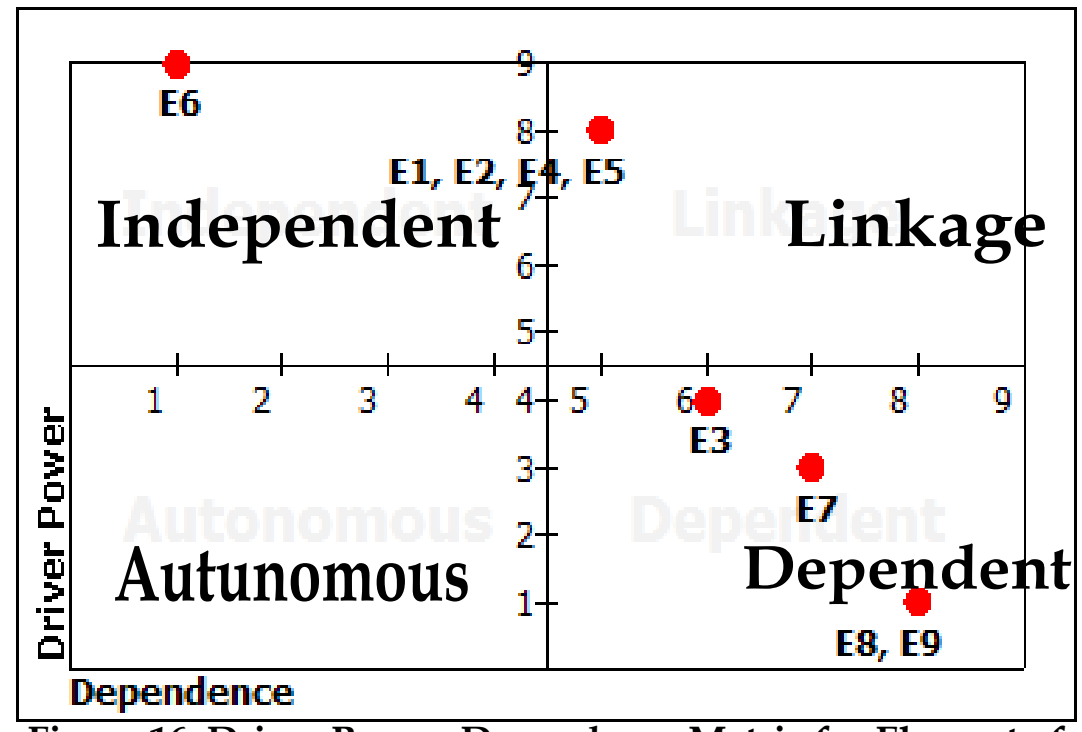

Figure 16: Driver Power-Dependence Matrix for Element of affected People Segment 


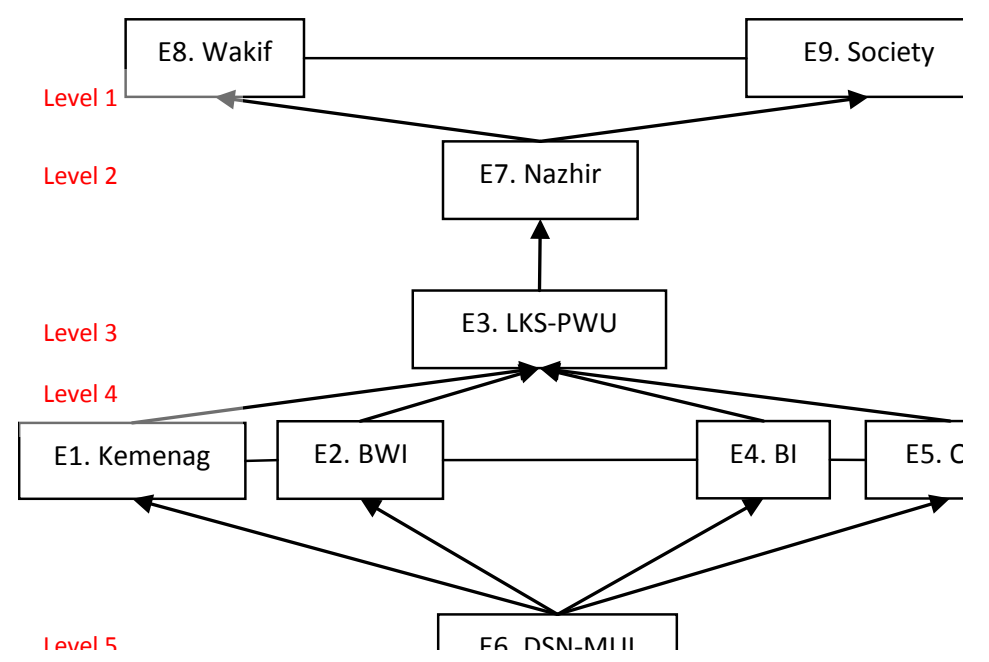

Figure 17: Structural Model for Element of Affected People Segment

The influence of DSN- account ortimedepositaccount. MUI is very storng to the Next, nazhir acts to persue sustainibility of cash waqf people to donate in the form of in Indonesia. The issuance cash waqf. Mutual cooperation of fatwa on May 11, 2002 among the involved parties is about cash waqf has been required to support the success the main legal basis of cash of cash waqf. waqf. Kemenag, BWI, BI, and OJK must coordinate to make regulations for the sustainibility of cash waqf and appoint LKSPWU as institutions thay may receive cash waqf investment Element of Effective Measurements

Results of ISM process is to be saved in demand deposits as follows:

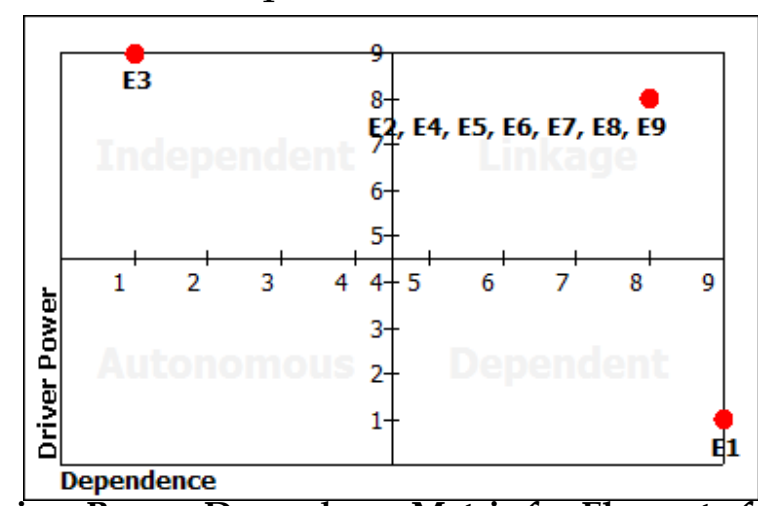

Figure 18: Driver Power-Dependence Matrix for Element of Effectiveness 
Sub-element (E1) The existence of legal support for achievement of optimal role cash waqf contained in the of LKS-PWU is in dependent independent sector, which is group which means they have an element of independent a close relationship with other variables that affect the other elements, but not the prime elements if there is a change.

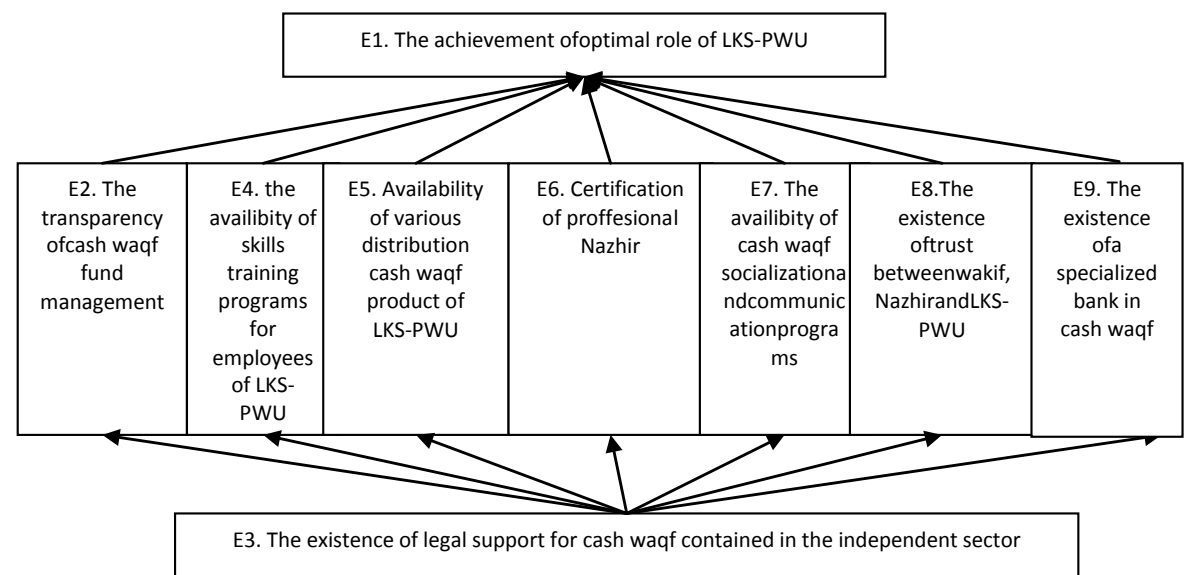

Figure 19: Structural Model for Element of Effectivity

mover of the system or it can be said as a result of the other elements. The other group is linkage group consisting of seven sub-elements: (E2) The transparency of cash waqf fund management, (E4) the availibity of skills training programs for employees of LKS-PWU, (E5) Availability of various distribution cash waqf product of LKS-PWU, (E6) Certification of proffesional Nazhir, (E7) The availibity of cash waqf socialization and communication programs, (E8) The existence of trust between wakif, Nazhir and LKS-PWU, (E9) The existence of a specialized bank in cash waqf. Sub-element (E3) the
The existence of legal support for cash waqf is the key sub-element. Strong legal protection may create a sense of safety to those who assist the collection of cash waqf. The effectiveness of this strategy can be achieved when the transparency of cash waqf funds management exists, when skills training programs for employees of LKS-PWU conducted, when various distribution cash waqf products have been offered by LKS-PWU, when proffessional nazhir is certified, when the program of socialization and communcation of cash waqf is conducted, when mutual trust among wakif, nazhir and 
LKS-PWU exists, and when a spesialized bank in cash waqf is established.

Key Sub-elements of Strategy to Enhance the Role of Islamic Banks to Fundraise Cash Waqf

Key Sub-elements is a sub-element used as a driving force, which is in its implementation need to be considered, because it can affect the success or failure of other sub-elements. The major key sub-elements in this study is the need of strong legal support for cash waqf as the optimalization of Islamic banks' role to receive cash waqf is very much dependent on it. Mikail (2013) and Siswantoro \& Dewi (2011) argued that the lack of support and participation of government cause ineffectiveness in waqf collection. Mu'allim and Abdurrahman (2014) also recommended tostrengthen the waqf regulation, institutions, and cooperation in order to develop cash waqf. The current system to conduct cash waqf is still unclear as some parties have difference perceptions in waqf management. Hence, it requires a strong coordination between BWI, Kemenag, BI, OJK, Nazhir and LKS-PWU in order to boost the role of LKSPWU. They must have same perception and do not express the ego of each institution.

Furthermore, in the elements of possible change, no prime mover is found in the system. Eight sub-elements are in the linkage group, which means they must be interrelated and then it must be implemented in the same time. Those sub-elements are standardization of the role of LKS-PWU which is based on the coordination among cash waqf stakeholders, transparency in the management of cash waqf funds using IT, knowledge/ expertise of LKS-PWU's employees about cash waqf, variations in the distribution cash waqf products available in LKS-PWU, providing certification for professional Nazhir, education, socialization and effective communication, and fostering good relations between wakif, Nazhir and LKS-PWU.

The prime mover
obstacle is the lack of socialization and education about the cash waqf. So far, public perception about cash waqf is still minimum. Therefore, it requires a movement of dissemination to the public through the mass media publications, advertising, early education about cash waqf and others. Some people still perceive that waqf is limited to physical waqf (Siswantoro 
and Dewi, 2011). Haron et al. (2016) argued that the government should increase their promotion efforts to raise the awareness of the wakif. They found that promotion and human resources are the main factors influencing cash waqf collection. Likewise, Harun et al. (2016) and Huda et al. (2012) also strongly suggested to have a more solid promotion programme that may increase awareness about waqf. in this case, Rusdiyana and Devi (2014) revealed the need to increase the ability of Nazhir and to build a special institution in waqf education.

Besides, the DSNMUI has an important role in influencing the public, with the release of fatwa of MUI about cash waqf on May 11, 2002. The fatwa became a strong legal foundation and give full support to the advancement of cash waqf in Indonesia. DSN-MUI is also tasked with observing the sustainability of cash waqf and to mediate between the parties involved if misunderstanding occurs.

\section{CONCLUSSION Summary}

The role of Islamic banks in the cash waqf management according to the law no. 41 year 2004 on waqf is as a recipient of cash waqf. Nazhir who collects cash waqf should deposit it in LKS-PWU to be invested in financial investments. The collected cash waqf could be in perpetual or in limited term.

Using ISM method, the research finds that the main key sub-elements is a strong legal support for cash waqf. Experts and practitioners agreed that legal support creates a sense of secure to those who involved in the cash waqf fundraising. In this case, the clarity system cash waqf is still unclear, since some parties have misperception of cash waqf. Hence, it requires a strong coordination between BWI, Kemenag, BI, OJK, Nazhir and LKS-PWU in order to boost the role of LKS-PWU. They must have same perception and do not prioritize the ego of each institution.

The most important actor is DSN-MUI since the whole activities must be compliant with sharia. Moreover, the most priority obstacle that must be solved is the lack of education/ socialization about cash waqf.

\section{Recommendations}

There are some recommendations for the stakeholders of cash waqf. First, Strengthening the coordination among some parties namely BWI, Kemenag, 
LKS-PWU and nazhir. Second, may initiate salary deduction designing an integrated for civil servants and information system thay employees of state-owned may be monitored by BWI, enterprises to pay waqf even Kemenag, nazhir and LKS- in a small amount. Fourth, PWU. The system should also LKS-PWU should provide a be able to help transparancy special counter to serve waqf of cash waqf management collection and information towards people as waqif. Third, about cash waqf programs.

Cash waqf programs must be more promoted. Government 


\section{References}

Al-Arif. (2010). Pemberdayaan Masyarakat Berbasis Wakaf Uang. Jurnal Asy-Syir'ah Fakultas UIN Sunan Kalijaga Yogyakarta, Vol. 44 No. II, pp. 813 - 828.

Ascarya, Gunadi, W., Cahyono, W.,Anwar, E., and Syarifuddin, F.(2012). Strategi Meningkatkan Preferensi Perbankan Syariah Indonesia Dalam Menggunakan Pembiayaan BagiHasil. Jakarta: Central Banking Education and Studies Department, Bank Indonesia.

Aula, M.A. (2012). Pemberdayaan Umat Melalui Lembaga Wakaf. Jurnal Al-Awqaf, Vol. V, No. 2.

Basyuni, M. (2015). Pengembangan Wakaf Korporasi Di Indonesia. Paper presented at Seminar Nasional Ekonomi Syariah, Ruang Rekreasi, Bank Indonesia, Jakarta, 30 Maret.

Bhattacharya, S., and Momaya, K. (2009). Interpretive Structural Modeling of Growth Enablers in Construction Companies. Singapore Management Review, Vol. 31, No. 1, pp. 73-97.

Cizakca, M. (1998).Awqaf in History and Its Implications for Modern Islamic Economies.Islamic Economic Studies, Vol 6, No 1, pp. 43-70.

Djunaedi, A, and Indra. (2015). Wawancara Wakaf Uang. BadanWakaf Indonesia, Jakarta, 21 April 2015.

Furqon. (2011).Analisis Praktek Perwakafan Uang Pada Lembaga Keuangan Syariah. Jurnal Walisongo, Vol. 19 No 1 pp. 157-178.

Haron, M., Kamarudin, M.K., Fauzi, N.A.M., Ariff, M.M., and Zainuddin, M.Z. (2016). International Journal of Business, Economics, and Law, Vol 9, Issue 2, pp 27-33.

Huda, M. (2013). Mekanisme Penciptaan Tata kelola Wakaf Kreatif di Indonesia.Jurnal Al-Awqaf, Vol. 6 No. 2 pp. 94107. 
Ibrahim, H., Amir, A., and Masron, T.A. (2013). Cash Waqf: An Innovative Instrument for Economic Development. International Review of Social Sciences and Humanities, Vol 6, No 1, pp 1-7.

Ministry of Religious Affairs of the Republic of Indonesia. (2006). Fiqih Wakaf. Jakarta.

Himpunan Peraturan Perundang-Undangan Tentang Wakaf. Jakarta: Direktorat Jenderal Bimbingan Masyarakat Islam Direktorat Pemberdayaan Wakaf.

Strategi Pengembangan Wakaf Tunai di Indonesia. Jakarta: Direktorat Jenderal Bimbingan Masyarakat Islam Direktorat Pemberdayaan Wakaf.

Marimin.(2004). Teknik dan Aplikasi Pengambilan Keputusan Kriteria Majemuk. Jakarta: Grasindo.

Mikail. (2013). Perspective Of SiyasahShar'iah In Application Of Cash WaqfTransfer For Islamic Financial Industry: Indonesian Study Case, Paper Proceeding of the 5th Islamic Economics System Conference (iECONS 2013), "Sustainable Development Through The Islamic Economics System", UniversitiSains Islam Malaysia, Kuala Lumpur, 4-5th September 2013.

Mu'alim \& Abdurrahman. (2014). Menggiatkan Wakaf Uang (Tunai) sebagai Upaya Peningkatan Kesejahteraan Masyarakat. Jurnal Bimas Islam Vol. 7 No. 4 pp. 727 - 753.

Nafis.(2011). Aplikasi Wakaf Uang di Indonesia. Jurnal Al-Awqaf, Vol. IV No. 02. pp. 37-50.

Nasution, Edwin, M., \&Hasanah, U. (2006).Wakaf Tunai Inovasi Finansial Islam. Jakarta: Program Studi Timur Tengah dan Islam Universitas Indonesia.

Nasution, M.E. (2012). Potensi Wakaf Uang Sungguh Luar Biasa. www.republika.co.id/berita/dunia-islam/ 
islamnusantara/12/07/22/m7jb3w-potensi-wakafuang-sungguh-luar-biasa. 22 Juli 2012 06:40 WIB.

Otoritas Jasa Keuangan.(2015). Siaran Pers OJK dan Perbankan Syariah Gelar Expo IB Vaganza 2015. Jakarta.

Osman, Faiz, A., Htay, Nu, S., and Muhammad, M.O. (2012). Determinants of Cash Waqf Giving In Malaysia: Survey Of Selected Works. http://irep.iium.edu.my/28284/1/ DETERMINANTS_OF_CASH_WAQF_GIVING_IN_ MALAYSIA.pdf.

Rusydiana, A and Devi, A. (2014).Analysis of Cash Waqf Fund Management in Indonesia: An Analytic Network Process (ANP) Method Approach. Presented at the $2^{\text {nd }}$ ASEAN International Conference on Islamic Finance, Royal Ambarukmo Hotel, November, 2014.

Sabit and Tahir, M. (2011). Permissibility of Establishing Waqf Bank in Islamic Law. International Conference on Sociality and Economics Development IPEDR vol.10. Singapore. IACSIT Press,

Farhah, Kayadibi, S., Polat, R., Fidan, Y., and Kayadibi, O. (2014). The Role of Cash Waqf in Poverty Alleviation: Case of Malaysia. Proeeding - Kuala Lumpur International Business, Economics and Law Conference 4 (KLIBEL4), Vol 1, 31 May - I June 2013, Hotel Putra, Kuala Lumpur, Malaysia.

Siswantoro, D\&Dewi, M.K. (2011). The Effectiveness of Cash Waqf Fund Raising through Mutual Fund in Indonesia: Essential readings in Contemporary Waqf Issues. Kuala Lumpur. CERT publication.

Ubaid, A. (2014). Kemitraan Nazhir Dengan Bank Syariah Dalam Mengembangkan Wakaf Uang: Studi Kasus Di Indonesia, Bangladesh, dan Yoordania. Jurnal Al-Awqaf, Vol. 7 No. 1.

Zamhari. (2011). Implementasi Lembaga Keuangan Syariah Dalam Pengembangan Wakaf Uang di Indonesia. Jurnal Al-Awqf, Vol. IV No. 02 pp. 51-60. 